\title{
Evaluation of transport conditions for autologous bone marrow-derived mesenchymal stromal cells for therapeutic application in horses
}

Miguel Espina, Henriette Jülke, Walter Brehm, Iris Ribitsch, Karsten Winter, Uta Delling

Background. Mesenchymal stromal cells (MSCs) are increasingly used for clinical applications in equine patients. For MSC isolation and expansion, a laboratory step is mandatory, after which the cells are sent back to the attending veterinarian. Preserving the biological properties of MSCs during this transport is paramount. The goal of the study was to compare transport-related parameters (transport container, media, temperature, time, cell concentration) that potentially influence characteristics of culture expanded equine MSCs.

Methods. The study was arranged in three parts comparing I) five different transport containers (cryotube, two types of plastic syringes, glass syringe, CellSeal), II) seven different transport media, four temperatures $\left(4^{\circ} \mathrm{C}\right.$ vs. room temperature; $-20^{\circ} \mathrm{C}$ vs. $\left.-80^{\circ} \mathrm{C}\right)$, four time frames ( 24 h vs. 48 h; 48 h vs. 72 h), and III) three MSC concentrations ( $5 \times 10^{6}$, $10 \times 10^{6}, 20 \times 10^{6} \mathrm{MSC} / \mathrm{ml}$ ). Cell viability (Trypan Blue exclusion; percent and total number viable cell), proliferation and trilineage differentiation capacity were assessed for each test condition. Further, the recovered volume of the suspension was determined in part I. Each condition was evaluated using samples of six horses $(n=6)$ and differentiation protocols were performed in duplicates.

Results. In part I of the study, no significant differences in any of the parameters were found when comparing transport containers at room temperature. The glass syringe was selected for all subsequent evaluations (highest recoverable volume of cell suspension and cell viability). In part II, media, temperatures, or time frames had also no significant influence on cell viability, likely due to the large number of comparisons and small sample size. Highest cell viability was observed using autologous bone marrow supernatant as transport medium, and "transport" at $4^{\circ} \mathrm{C}$ for $24 \mathrm{~h}$ (70.6\% vs. control group $\left.75.3 \%\right)$; this was not significant. Contrary, viability was unacceptably low (<40\%) for all freezing protocols at $-20^{\circ} \mathrm{C}$ or $-80^{\circ} \mathrm{C}$, particularly with bone marrow supernatant or plasma and DMSO. In part III, various cell concentrations had also no significant influence on any of the evaluated parameters. Chondrogenic differentiation showed a trend towards being decreased for all transport conditions, compared to control cells. 
Discussion. In this study, transport conditions were not found to impact viability, proliferation or ability for trilineage differentiation of MSCs, most likely due to the small sample size and large number of comparisons. The unusual low viability after all freezing protocols is in contrast to previous equine studies. Potential causes are differences in the freezing, but also in thawing method. Also, the selected container (glass syringe) may have impacted viability. Future research may be warranted into the possibly negative effect of transport on chondrogenic differentiation. 


\section{Evaluation of transport conditions for autologous bone marrow-derived mesenchymal}

\section{stromal cells for therapeutic application in horses}

1

2 Miguel Espina $^{1}$, Henriette Jülke ${ }^{2}$, Walter Brehm ${ }^{1}$, Iris Ribitsch ${ }^{2,3}$, Karsten Winter ${ }^{2,4}$, Uta Delling ${ }^{1}$

3

41 Large Animal Clinic for Surgery, Faculty of Veterinary Medicine, University of Leipzig,

$5 \quad$ Leipzig, Germany

62 Translational Centre for Regenerative Medicine (TRM), University of Leipzig,

$7 \quad$ Leipzig, Germany

83 Current address: Equine Hospital, University of Veterinary Medicine, Vienna, Austria

94 Current address: Institute of Anatomy, Faculty of Medicine, University of Leipzig, Leipzig,

10 Germany

11

12 Corresponding author:

13 Uta Delling 1

14 An den Tierkliniken 21, 04103 Leipzig, Germany

15 Email address: delling@vetmed.uni-leipzig.de

16 


\section{Abstract}

20 Background. Mesenchymal stromal cells (MSCs) are increasingly used for clinical applications

21 in equine patients. For MSC isolation and expansion, a laboratory step is mandatory, after which

22 the cells are sent back to the attending veterinarian. Preserving the biological properties of MSCs

23 during this transport is paramount. The goal of the study was to compare transport-related

24 parameters (transport container, media, temperature, time, cell concentration) that potentially

25 influence characteristics of culture expanded equine MSCs.

26 Methods. The study was arranged in three parts comparing I) five different transport containers

27 (cryotube, two types of plastic syringes, glass syringe, CellSeal), II) seven different transport 28 media, four temperatures $\left(4^{\circ} \mathrm{C}\right.$ vs. room temperature; $-20^{\circ} \mathrm{C}$ vs. $\left.-80^{\circ} \mathrm{C}\right)$, four time frames $(24 \mathrm{~h}$ vs. $48 \mathrm{~h} ; 48 \mathrm{~h}$ vs. $72 \mathrm{~h})$, and III) three MSC concentrations ( $\left.5 \times 10^{6}, 10 \times 10^{6}, 20 \times 10^{6} \mathrm{MSC} / \mathrm{ml}\right)$.

30 Cell viability (Trypan Blue exclusion; percent and total number viable cell), proliferation and 31 trilineage differentiation capacity were assessed for each test condition. Further, the recovered

32 volume of the suspension was determined in part I. Each condition was evaluated using samples

33 of six horses $(n=6)$ and differentiation protocols were performed in duplicates.

34 Results. In part I of the study, no significant differences in any of the parameters were found

35 when comparing transport containers at room temperature. The glass syringe was selected for all 36 subsequent evaluations (highest recoverable volume of cell suspension and cell viability). In part

37 II, media, temperatures, or time frames had also no significant influence on cell viability, likely

38 due to the large number of comparisons and small sample size. Highest cell viability was

39 observed using autologous bone marrow supernatant as transport medium, and "transport" at $4^{\circ} \mathrm{C}$

40 for $24 \mathrm{~h}(70.6 \%$ vs. control group $75.3 \%)$; this was not significant. Contrary, viability was 
41 unacceptably low $(<40 \%)$ for all freezing protocols at $-20^{\circ} \mathrm{C}$ or $-80^{\circ} \mathrm{C}$, particularly with bone

42 marrow supernatant or plasma and DMSO. In part III, various cell concentrations had also no

43 significant influence on any of the evaluated parameters. Chondrogenic differentiation showed a

44 trend towards being decreased for all transport conditions, compared to control cells.

45 Discussion. In this study, transport conditions were not found to impact viability, proliferation or

46 ability for trilineage differentiation of MSCs, most likely due to the small sample size and large

47 number of comparisons. The unusual low viability after all freezing protocols is in contrast to

48 previous equine studies. Potential causes are differences in the freezing, but also in

49 thawing method. Also, the selected container (glass syringe) may have impacted viability. Future

50 research may be warranted into the possibly negative effect of transport on chondrogenic

51 differentiation.

52

53

56

\section{Introduction}

Mesenchymal stromal cells (MSCs) are increasingly applied for various diseases in humans (Sharma et al., 2014) and animals (Guercio et al., 2012; Smith, Garvican \& Fortier, 2014). In the equine patient, MSCs are used locally, predominantly to treat tendon and ligament injuries (Godwin et al., 2012; Smith et al., 2013). The benefit of MSC injection to treat joint diseases is less well established (Ferries et al., 2014). Mesenchymal stromal cells can be isolated from multiple body tissues including bone marrow (BM), adipose tissue and blood (Sharma et al., 2014; Smith, Garvican \& Fortier, 2014). Following isolation, MSCs need to be expanded in 
64 culture to provide adequate cell numbers for clinical use. Shipping conditions for transportation

65 of expanded cells to the patient should ensure stem cell viability and maintenance of original cell

66 characteristics, such as purity, identity, differentiation, and proliferation capacity. Various

67 shipping conditions are being used for the transport of expanded MSCs to the equine patient, but

68 details of validation experiments in horses are either not reported (Godwin et al., 2012), only

69 unfrozen conditions were evaluated (Bronzini et al., 2012; Mercati et al., 2014) or only one

70 frozen condition was evaluated (Garvican et al., 2014). Specifically, Bronzini et al. (2012) used

71 blood-derived MSCs $(\mathrm{n}=10)$ and compared 10 different transport media at $4^{\circ} \mathrm{C}$, room

72 temperature (RT), and $37^{\circ} \mathrm{C}$ for up to $72 \mathrm{~h}$ using "sterile tubes" of unspecified origin. Mercati et

73 al. (2014) however, used fat-derived MSCs $(\mathrm{n}=2)$, assessed one transport media at $4^{\circ} \mathrm{C}$ vs. $\mathrm{RT}$,

74 for $24 \mathrm{~h}$ and $48 \mathrm{~h}$; the origin of the transport container was not specified either. Finally, Garvican

75 et al. (2014) evaluated BM-derived MSCs $(n=3)$ in 7 different media at $4-8^{\circ} \mathrm{C}$ and one medium at

$76-78^{\circ} \mathrm{C}$ for up to $72 \mathrm{~h}$, using a single type of specified cryotubes. A recent study focused

77 specifically on short-term (2-5 d) cryopreservation (liquid nitrogen) of equine BM-derived MSCs

$78(\mathrm{n}=9)$ prior to implantation (Mitchell et al., 2015). In this study six different transport media

79 compositions were tested including different serum preparations, varying concentrations of

80 dimethyl sulfoxide (DMSO), and culture medium. There were no significant differences between

81 the different media. The authors concluded that clinicians may prefer a combination of

82 autologous serum and low DMSO concentration for frozen MSC transport prior to clinical use.

83 When shipping unfrozen cells, it appears that RT is superior to $37^{\circ} \mathrm{C}$ or $4^{\circ} \mathrm{C}$ when shipping times

84 do not exceed 12 hours (Bronzini et al., 2012). With longer shipping times, keeping the cells at

$854^{\circ} \mathrm{C}$ resulted in higher viability compared to RT (Mercati et al., 2014). Further, superior results

86 were obtained using phosphate buffered saline (PBS) compared to culture medium with or 
87 without blood serum or fetal bovine serum (FBS) as transport media at temperatures above $0^{\circ} \mathrm{C}$

88 for up to $12 \mathrm{~h}$ (Bronzini et al., 2012). Others report no significant difference in cell viability after

$8912 \mathrm{~h}$ and $24 \mathrm{~h}$ in all transport media, but found the most rapid decline in viability over time in

90 suspensions containing biological fluids such as BM aspirate, platelet-rich plasma or serum.

91 Interestingly and in contrast to Bronzini et al. (2012), the least decline in viability was observed

92 with culture medium containing FBS (Garvican et al., 2014). Transport of frozen equine MSCs

$93\left(90 \%\right.$ allogenic blood serum $+10 \% \mathrm{DMSO} ;-78^{\circ} \mathrm{C}$; up to $\left.72 \mathrm{~h}\right)$ resulted in MSC viability of

$94 \sim 80 \%$ (Garvican et al., 2014). A similar high viability (80-90\%) was described by Mitchell et al.

95 (2015). However, it should be emphasized that in both articles an invasive thawing method is

96 described, which is unlikely to be practically feasible.

97 For the transport of frozen MSCs, it has to be considered that cryopreservation may impair stem

98 cell functionality and engraftment of human blood-derived hematopoietic stem cells (Lioznov et

99 al., 2008). Also, there have been reports of altered immunosuppressive properties of human

100 MSCs following cryopreservation (François et al., 2012).

101 The important aspect of cell viability can be assessed in multiple ways, including manual or

102 automated counting. Further, viability is usually expressed as percent of viable cells but the

103 actual number of viable cells can be determined as well. Based on the four previous publications

104 regarding transport of equine MSCs for immediate clinical use (Bronzini et al., 2012; Mercati et

105 al., 2014; Garvican et al., 2014; Mitchell et al., 2015) no data of the total number of viable cell

106 after a simulated transport are available.

107 Another unknown variable is the influence of the transport container, since plastic adherence is a

108 key feature of MSC characteristics. Furthermore, it is known that both surface chemistry and

109 biochemical signals affect MSC proliferation and differentiation (Almodóvar et al., 2010; Wang 
110 et al., 2015). Cryotubes are most frequently used in practical settings and in previous comparable

111 studies (Garvican et al., 2014; Mitchell et al., 2015); others did not specify the container under

112 investigation (Bronzini et al., 2012; Mercati et al., 2014).

113 Finally, the concentration of cells during transport may impact MSC characteristics. It has been

114 stated that cell concentration may influence biological properties of hematopoietic stem cells

115 (Dlimi, 2012). Also, cell concentration appears to have an impact on cell viability in non-MSC

116 cell lines (De Loecker et al., 1998; Costa et al., 2000).

117 Therefore, the aim of this present study was to determine the impact of temperature during

118 transport, transport media, transport times, transport containers, and MSC concentrations on

119 equine, BM-derived MSC characteristics.

120 Our hypotheses were that 1) transport container, 2) transport media, temperature and time, and 3)

121 MSC concentration have an effect on MSC viability, proliferation and trilineage differentiation

122 capacity.

123

\section{Material and Methods}

126 Study design and general procedures

127

128 Study design

129

130 The study entailed three consecutive parts in which preceding results were applied in the

131 subsequent steps (Fig. 1). In all conditions and controls, cell quality was assessed with respect to

132 viability (percent, total number viable cells), proliferation and trilineage differentiation capacity. 
133 In part I, recoverable cell suspension volume for the different containers was determined

134 additionally. The most suitable container was subsequently used throughout the study. In part II,

135 different transport media were tested in positive (four types of transport media) and negative

136 (three types of transport media) temperatures, each for two time frames ( 24 and $48 \mathrm{~h}, 48$ and $72 \mathrm{~h}$,

137 respectively). This amounted to 28 different test conditions: 16 at temperatures above $0^{\circ} \mathrm{C}$ and 12

138 within the negative temperature range. Finally, in part III, three different MSC concentrations

139 were compared using the best transport media/temperature/time combination as determined in

140 part II. A total of six test conditions were compared; three for the positive and negative

141 temperature, respectively. Controls for each condition were the cell characteristics at time point

1420 , immediately before each test condition was started. In each of the three parts of the study, the

143 conditions were always evaluated using MSCs of six different horses ( $n=6)$. Further, all MSC

144 differentiation protocols were performed in duplicates.

145

146 Sampling of BM and venous blood

148 All experiments were approved by the State Animal Care Committee (V12/09, Landesdirektion

149 Leipzig, Free State of Saxony, Germany). Bone marrow was harvested from the sternum of 11

150 Warmblood geldings. Seven horses were sampled twice and used for two parts of the study (over

151 six months between the aspirations). The horses were aged between 15-16 years and the

152 procedure was performed as previously described (Delling et al., 2012). Briefly, after

153 intravenous sedation with $0.06 \mathrm{mg} / \mathrm{kg}$ romifidine (Sedivet; Boehringer Ingelheim, Ingelheim,

154 Germany) and $0.02 \mathrm{mg} / \mathrm{kg}$ butorphanol (Torbugesic; Fort Dodge Veterinär, Würselen, Germany),

155 the area of the sternum was aseptically prepared and locally anesthetized. A BM aspiration 
156 needle (Bone Marrow Harvest Needle, Angiotech, Gainesville, USA) was advanced into the

157 bone and $2 \times 20 \mathrm{ml}$ marrow was aspirated into heparinized syringes (10,000 IU heparin-sodium

158 [B.Braun, Melsungen, Germany]/20 ml syringe). Further, 2 x $20 \mathrm{ml}$ venous blood samples were

159 obtained from the jugular vein for the production of autologous plasma using heparinized

160 syringes as described above.

161

162 Processing of BM and venous blood

163

164 Within $4 \mathrm{~h}$ after sampling, the BM was centrifuged in $50 \mathrm{ml}$ conical tubes (Falcon Tube, BD

165 Biosciences, Erembodegem, Belgium; $10 \mathrm{~min}, 600 \mathrm{x} \mathrm{g}, 10^{\circ} \mathrm{C}$ ). The bone marrow supernatant

166 (BMS) was collected, filtered (BD Falcon cell strainer, BD Bioscience), and stored at $-80^{\circ} \mathrm{C}$ for

167 further use. From the remaining cellular fraction of the BM, mononuclear cells (MNCs) were

168 isolated by density gradient centrifugation. Briefly, the cellular fraction was diluted with PBS

169 (PAA, Pasching, Austria), layered on 15 ml Ficoll-Paque Premium (GE Healthcare, Uppsala,

170 Sweden) and centrifuged (20 min, $\left.1000 \times \mathrm{g}, 20^{\circ} \mathrm{C}\right)$. The buffy coat containing MNCs was

171 collected, washed twice with PBS and seeded in one $\mathrm{T}_{75}$ tissue culture flasks (Greiner bio-one,

172 Frickenhausen, Germany) containing culture medium, i.e. Dulbecco's modified Eagle Medium

173 (DMEM) low-glucose (PAA) supplemented with 10\% FBS (Sigma Aldrich, Steinheim,

174 Germany), 1\% penicillin/streptomycin (PAA) and $8.9 \mu \mathrm{g} / \mathrm{ml}$ ascorbic acid (Sigma). Cell cultures

175 were kept at $37^{\circ} \mathrm{C}$ in a humidified atmosphere at $5 \% \mathrm{CO}_{2}$. After $24 \mathrm{~h}$, the adherent cells were

176 washed with PBS and culture medium was added again. For the remaining expansion period,

177 culture medium was changed twice a week until cells reached subconfluency $(\mathrm{p} 0)$. 
178 In parts I and III of the study, cryopreserved MSCs were used, whereas fresh cells were

179 evaluated in part II. For the latter, harvested MSCs of $\mathrm{p} 0$ were further expanded until p3 by

180 plating 500,000 $\mathrm{MSC} / \mathrm{T}_{175}$ tissue culture flasks and maintaining the above mentioned culture

181 conditions. In contrast, MSCs for parts I and III were cryopreserved at p0 for later use. For this,

$182 \mathrm{MSC}(\mathrm{p} 0)$ suspension was centrifuged $\left(5 \mathrm{~min}, 600 \mathrm{xg}, 4^{\circ} \mathrm{C}\right)$ and the obtained cell pellet was

183 resuspended in FBS supplemented with 10\% DMSO (Sigma Aldrich, Steinheim, Germany). The

184 suspension was transferred into cryotubes (Greiner Bio-One, Frickenhausen, Germany) and

185 temperature was decreased stepwise at a rate of $1{ }^{\circ} \mathrm{C} / \mathrm{min}$ to $-80^{\circ} \mathrm{C}$ using a freezing container

186 (Nalgene Mr. Frosty, Nalge Nunc, Rochester, USA). After $12 \mathrm{~h}$ maintenance at $-80^{\circ} \mathrm{C}$ in a

187 freezer, the temperature was lowered further to $-150^{\circ} \mathrm{C}$ in a freezer where cells were stored until

188 further use. For thawing, the samples were placed in a $37^{\circ} \mathrm{C}$ water bath. The MSCs were

189 transferred to conical tubes, washed with PBS and centrifuged $\left(5 \mathrm{~min}, 600 \times \mathrm{g}, 4^{\circ} \mathrm{C}\right)$. The

190 obtained cell pellet was suspended in culture medium and expanded as mentioned above until p3.

191

192 A hemocytometer (Neubauer-improved, Marienfeld-Superior, Lauda-Königshofen, Germany)

193 was used for cell counting throughout the study.

194 Autologous blood plasma was harvested and stored in an identical manner as the BMS.

195

196 MSC viability testing

198 Cell viability was determined using Trypan Blue stain (Sigma) and the fraction of unstained

199 (viable) cells was determined manually. Viability was expressed as percent of viable cells;

200 additionally, the total viable cell count per condition was determined. 
202 Proliferation capacity

203

204 To allow comparison of MSC growth characteristics, cumulative doubling rates were calculated

205 for each condition as previously described (Giovannini et al., 2008). For this, cells (p4) were

206 plated at a density of 500 cells $/ \mathrm{cm}^{2}$ on $\mathrm{T}_{25}$ tissue culture flasks in culture medium. After seven

207 days in culture, the total number of MSCs per sample was assessed. The process was repeated at

208 weekly intervals until p7. The population doublings were calculated with the equation PD $=$

$209 \log 10\left(\mathrm{~N} / \mathrm{N}_{0}\right) \times 3.33$, where $\mathrm{N}$ is the number of harvested cells and $\mathrm{N}_{0}$ the number of plated cells.

210 Cumulative population doublings (cPD) for each time point were calculated by adding values of

211 all previous PDs.

212

213 Trilineage differentiation potential

214

215 For adipogenesis, a modified protocol was used (Giovannini et al., 2008). Briefly, cells (p4) were

216 seeded in duplicate at a density of 5000 cells $/ \mathrm{cm}^{2}$ in 12-well plates (Greiner). At subconfluency,

217 induction medium was added consisting of DMEM/Ham's F12 (PAA), 5\% rabbit serum (Sigma),

218 10\% FBS, 1\% penicillin/streptomycin, $1 \mu \mathrm{M}$ dexamethasone (Sigma), $100 \mu \mathrm{M}$ indomethacine

219 (Sigma) and $500 \mu \mathrm{M}$ 3-IBMX (3-isobutyl-1-methylxanthine; Sigma), as well as 1,700 nM

220 insulin (Invitrogen, Karlsruhe, Germany) and maintained for $72 \mathrm{~h}$. Afterwards, cells were fixed

221 with 4\% paraformaldehyde (Roth, Karlsruhe, Germany) and the production of intracellular lipid

222 droplets was assessed semi-quantitatively by $0.35 \%$ Oil red O staining (Sigma) counterstained 
223 with Mayer hematoxilin (Sigma) and assigning scores of 0-3 for no, low, medium or high

224 numbers of visible fat droplets. Representative images are depicted in Fig. 2.

225 For osteogenesis, cells (p4) were seeded in duplicate at a density of $5000 \mathrm{cell} / \mathrm{s} / \mathrm{cm}^{2}$ in 12 -well

226 plates. At subconfluency, differentiation was induced in DMEM/Ham's F12, 10\% FBS, 1\%

227 penicillin/streptomycin supplemented with $10 \mathrm{nM}$ dexamethasone, $10 \mathrm{mM}$ ß-glycerophosphate

228 (Sigma) and $0.1 \mathrm{mM}$ ascorbic acid. The medium was changed twice a week. Early and late

229 osteogenesis was evaluated using an alkaline phosphatase stain (Sigma) and Alizarin red stain

230 (Sigma) at day 14 and 21 after induction, respectively. Both stains were assessed semi-

231 quantitatively by assigning scores of 0-3 for no, low, medium and high blue intracellular staining

232 and red stained-extracellular calcium deposition, respectively. Representative images are

233 depicted in Fig. 2.

234 Chondrogenesis was induced in micromass pellet cultures (p4) (Giovannini et al., 2008). To

235 exclude non-viable cells after the simulated transport, all recovered cells were cultured routinely

236 for $12 \mathrm{~h}$. Following, only adherent cells were harvested and pellets were prepared as $5 \times 10^{5}$ cells

237 in duplicate, placed in $15 \mathrm{ml}$ tubes and centrifuged $\left(5 \mathrm{~min}, 280 \mathrm{x} \mathrm{g}, 4^{\circ} \mathrm{C}\right)$. Pellets were incubated

238 in chondrogenic medium consisting of DMEM high glucose (4.5 g/l; PAA) supplemented with

$2391 \%$ ITS + Premix (BD Biosciences), $0.1 \mu \mathrm{M}$ ascorbic acid, $0.4 \mu \mathrm{M}$ proline (Roth), $100 \mathrm{nM}$

240 dexamethasone and $10 \mathrm{ng} / \mathrm{ml}$ human recombinant TGF- $\beta_{1}$ (BD Biosciences). Medium was

241 replaced twice a week. After 21 days in chondrogenic culture, pellets were fixed for $24 \mathrm{~h}$ in $4 \%$

242 paraformaldehyde, dehydrated, embedded in paraffin and cut into $4 \mu \mathrm{m}$ thick sections. Histologic

243 sections were stained with Safranin O-fast green (Sigma) and Alcian blue (Sigma) to detect

244 extracellular glycosaminoglycan depositions. Masson trichrome staining (Sigma) was performed

245 to evaluate collagen synthesis. All slices were assessed semi-quantitatively using an established 
246 scoring system (Bern Score) based on Safranin O-fast green stains and with a maximal score of

247 nine (Grogan et al., 2006). A staining scale from 0 to 3 was used for Alcian blue and Masson

248 trichrome stained sections, respectively. Representative images are depicted in Fig. 2.

249 All histologic slides were scored at 10-20x magnification. Evaluation of the chondrogenic

250 differentiation was blinded to experimental conditions, whereas complete blinding of the

251 adipogenic and osteogenic differentiation was impeded by the consecutive order in the 12-well

252 plates known to the investigator.

253

254 Part I: Evaluation of transport containers

255

256 Each condition was tested using BM samples of six horses. Cells of $\mathrm{p} 3$ were divided into six 257 aliquots. The first aliquot served as control (time point 0 ) without further manipulation. The 258 remaining five aliquots ("transport groups") were transferred to five different transport 259 containers: 1) cryotubes (Art No 126263, Greiner), 2) plastic syringe/plastic tipped plunger

260 (Injekt Innohep, B. Braun), 3) plastic syringe/rubber tipped plunger (Art No 370-003, Henry

261 Schein Vet, Hamburg, Germany), 4) glass syringe/rubber tipped plunger (Art No 663570002,

262 513010007, and 423040001, Gerresheimer, Düsseldorf, Germany), and 5) CellSeal (CellSeal, 2

263 ml Needleless Port Foil Covered- Long Tubing Art No 10223-700-47, General Biotechnology,

264 Indianapolis, USA) (Fig. 3). The standardized conditions for the "transport groups" entailed a

265 cell concentration of $10 \times 10^{6} \mathrm{MSC} / \mathrm{ml}$, use of $500 \mu \mathrm{l}$ cell suspension per container $\left(5 \times 10^{6}\right.$

$266 \mathrm{MSC} /$ container), DMEM high glucose $+20 \% \mathrm{FBS}$ as transport media, and the maintenance for

26724 hours at $\mathrm{RT}\left(21^{\circ} \mathrm{C}\right)$ under light protection within the laboratory. After 24 hours, containers

268 were gently agitated, the contents expelled from the containers into conical tubes and the 
269 recoverable volume was measured using a micropipette. Viability, proliferation and

270 differentiation capacity were assessed as described above. Subjective handling characteristics of

271 the individual containers concerning content recovery and ease of use were recorded.

272

273 Part II: Evaluation of transport media, temperature and time

274

275 The glass syringe was selected to be used as transport container in part II and III based on results of part I. Again, each condition was tested using BM samples of six horses. Cells of p3 were divided into 29 aliquots: one aliquot served as control (without additional manipulation) and 28 aliquots were used for further testing. Four different transport media, specifically a) PBS, b)

279 280 281 282 283 284 285 286 287 288 289 290 autologous BMS, c) autologous blood plasma, and d) HypoThermosol FRS (HypoThermosol FRS, BioLife Solutions, Bothell, USA), were tested at RT and $4^{\circ} \mathrm{C}$, each for a $24 \mathrm{~h}$ and a $48 \mathrm{~h}$ "transport" time. The temperature of $4^{\circ} \mathrm{C}$ was maintained in a refrigerator. Three different transport media, specifically a) CryoStor CS10 (BioLife Solution; which contains 10\% DMSO), b) autologous BMS $+10 \%$ DMSO, and c) autolougous blood plasma $+10 \%$ DMSO, were tested at $-20^{\circ} \mathrm{C}$ and $-80^{\circ} \mathrm{C}$, each for a $48 \mathrm{~h}$ and $72 \mathrm{~h}$ "transport" time. Again, each glass syringe contained $500 \mu \mathrm{l}$ cell suspension at a concentration of $10 \times 10^{6} \mathrm{MSC} / \mathrm{ml}\left(5 \times 10^{6} \mathrm{MSC} /\right.$ container $)$. The freezing protocol was adapted for the glass syringe. Specifically, the MSC suspension was placed into the glass syringe via the syringe tip using a pipette. The tip was closed with a sterile cap (Art No 520010006, Gerresheimer). The plastic plunger was unscrewed from its rubber tip and the syringe covered loosely with flexible wrap (Parafilm, Bemis, Neenah, USA), The ensuing freezing protocol is described above; the glass syringe without plunger fits into the freezing container similar to the cryotube. Temperatures of $-20^{\circ} \mathrm{C}$ and $-80^{\circ} \mathrm{C}$ were maintained in 
292 freezers with integrated thermometers. Thawing was also similar as described previously.

293 Specifically, the glass syringe was placed in a $37^{\circ} \mathrm{C}$ water bath until no ice was visible within the 294 suspension. The flexible wrap was removed, the plunger screwed back on the rubber plunger tip 295 and the content expelled for further evaluation. At the end of each simulated transport viability, 296 proliferation and differentiation capacity were assessed as described above.

297

Part III: Evaluation of cell concentration

300 Conditions with the highest median cell viability in part II at temperatures above and below $0^{\circ} \mathrm{C}$, 301 respectively (\#5: BMS, $4^{\circ} \mathrm{C}, 24 \mathrm{~h}$; \#26: CryoStor, $-20^{\circ} \mathrm{C}, 72 \mathrm{~h}$ ) were further investigated in part

302 III. Specifically, cells of $\mathrm{p} 3$ were divided and placed at concentrations of $5 \times 10^{6}, 10 \times 10^{6}$, or 20

$303 \times 10^{6}$ MSCs per $\mathrm{ml}$ transport media into glass syringes ( $1 \mathrm{ml}$ suspension/container). Each

304 condition was tested using BM samples of six horses. In contrast to part I and II, the control

305 condition (time point 0 ) in this group additionally entailed the application of the MSC suspension

306 into the glass syringe and immediate withdrawal from the syringe. This means that the control

307 underwent the handlings of the "transport" itself, except for the actual time lapse of the transport.

308 This step was added to specifically assess the influence of the manipulation using the syringe vs.

309 the influence of the transport itself. The freezing and thawing of the MSC suspension within the

310 glass syringe was performed identically as described in part II. Viability, proliferation and

311 differentiation capacity were assessed as described above after $24 \mathrm{~h}$ (for temperatures above $0^{\circ} \mathrm{C}$ )

312 or $72 \mathrm{~h}$ (for temperatures below $0^{\circ} \mathrm{C}$ ).

313

314 Data analysis 
316 Data were tested for normal distribution using the Shapiro-Wilk test. Comparisons between the

317 individual conditions were made using Friedman- and Wilcoxon-Tests. Significance was set at $p$

$318<0.05$. Post-hoc Bonferroni correction was applied to adjust the p-value. Data were expressed as

319 median and interquartile range (IQR). Statistical analysis was performed with IBM SPSS

320 Statistics (version 22, Armonk, New York, USA).

321

322 Results

323

324 Part I: Evaluation of transport containers

325

326 The recovered volume after "transportation" was highest from the glass syringes (container 4;

$32791 \%, 453 \mu 1$ IQR $16 \mu 1)$ and lowest from CellSeal $(78 \%, 390 \mu 1$ IQR 35 4 l). Plastic syringes 2) and

328 3) yielded volumes of $88 \%(440 \mu 1$ IQR $35 \mu 1)$ and $90 \%(450 \mu 1$ IQR $19 \mu 1)$, respectively. The

329 cryotubes yielded a volume of $83 \%(415 \mu \mathrm{I}$ IQR $40 \mu \mathrm{l})$. Differences between the five containers

330 were not significant. Figure 4 depicts the five containers after $24 \mathrm{~h}$ of "transport" and

331 immediately before evacuation. Note the cell pellet which formed at the bottom of all containers.

332 Subjectively, we noticed foam formation after the content had been agitated in the cryotube

333 (container 1) and CellSeal (container 5), thus decreasing the recoverable volume. Upon pushing

334 the plunger of the syringes to expel the cell suspension, the glass syringe allowed for smooth,

335 controlled delivery of the cell suspension, whereas both plastic syringes tended to have an

336 irregular resistance during content delivery. 
337 Viability assessed by Trypan Blue staining was lower in all transport groups compared to the

338 control group, i.e. viability at time point 0 (76.8\% IQR 14.6\%), although this was not statistically

339 significant. There was also no significant difference in viability (\%) and the total number viable

340 cells between the five containers (Table 1). The highest viability was observed in glass syringes,

341 followed by the plastic syringe/rubber tipped plunger, the cryotube, CellSeal, and the plastic

342 syringe/plastic tipped plunger.

343 Proliferation capacity, adipogenic, early and late osteogenic differentiation as well as

344 chondrogenic differentiation were not significantly affected by the containers and there were no

345 differences compared to the control group. Results of the chondrogenic differentiation are given

346 in Table 2.

347 Based on the highest volume of recovery, subjective ease of use, and highest cell viability among

348 the transport groups, the glass syringe (container 4) was chosen as being the most suitable

349 container for the subsequent evaluation.

350

351 Part II: Evaluation of transport media, temperature and time

352

353 Viability in all test conditions was decreased compared to the control group (Fig. 5, Table 3).

354 Subjectively, at temperatures above $0^{\circ} \mathrm{C}$, cells generally had higher viabilities after 24 hours of 355 "transport" compared to 48 hours of "transport". Furthermore, cells kept at $4{ }^{\circ} \mathrm{C}$ tended to have 356 higher viability than cells kept at RT. With respect to the transport media, we observed highest 357 viabilities with BMS and plasma. None of these observations reached significance due to 358 Bonferroni correction (significance level $\mathrm{p}<0.002$ ) and the large number of comparisons. The 359 highest viability of $70.6 \%$ within the positive range was observed with condition $\# 5$ (BMS, $4^{\circ} \mathrm{C}$, 
36024 h). Regarding the total number viable MSCs higher cell counts were also obtained using BMS

361 or blood plasma in suspension. Specifically, the two highest numbers were 3.61 and $3.40 \times 10^{6}$

362 MSC (\#7 BMS, RT, $24 \mathrm{~h}$ and \#5 BMS, $4^{\circ} \mathrm{C}, 24 \mathrm{~h}$, respectively). Almost for all conditions the

363 cell count decreased from $24 \mathrm{~h}$ to $48 \mathrm{~h}$.

364 Within temperatures below $0^{\circ} \mathrm{C}$, the highest cell viability and the highest total number viable

365 cells were found using CryoStor (\#25-28). Among these, test condition \#26 (CryoStor, $-20^{\circ} \mathrm{C}, 72$

366 h) performed best, albeit not statistically significant. Proliferation capacity, adipogenic, early and

367 late osteogenic differentiation were not affected by any of the "transport" conditions compared to

368 the control group. However, data for conditions \#17-24 was not collected due to insufficient cell

369 numbers harvested after the simulated transport.

370 All tested conditions had lower Bern scores (Safranin O/Fast green stain) compared to the

371 control group, indicating a decreased presence of mature proteoglycans (Fig. 6), but this was not

372 statistically significant. Scores for the Alcian blue stain were similar to those for the Bern scores.

373 Collagen deposition, evaluated on Masson-Trichrom-stains, was not affected by any of the tested 374 conditions.

375

376 Part III: Evaluation of cell concentration

377

378 We did not observe significant differences in viability compared to the control group or between 379 any of the three evaluated MSC concentrations after transport, using conditions \#5 (BMS, $4^{\circ} \mathrm{C}$,

$38024 \mathrm{~h}$ ) and $\# 26$ (CryoStor, $-20^{\circ} \mathrm{C}, 72 \mathrm{~h}$ ) (Fig. 7, Table 4), although subjectively, viability (\%)

381 following both transport conditions was consistently lower than in the control group.

382 Importantly, in this part of the study, the control group MSCs was handled the same way as the 
383 "transport" group, but without the time lapse for the "transport". It is remarkable, that

384 manipulation alone, including the preparation for the cell counting procedure, resulted in a

385 considerable loss of cells. The cell deficits in the control group were $27.8 \%$ (for $20 \times 10^{6}$

$386 \mathrm{MSC} / \mathrm{ml}$ ), $30.2 \%$ (for $10 \times 10^{6} \mathrm{MSC} / \mathrm{ml}$ ) and $43.2 \%$ (for $5 \times 10^{6} \mathrm{MSC} / \mathrm{ml}$ ).

387 Cell proliferation and trilineage differentiation capacity were not affected by the test conditions.

\section{Discussion}

391 The current study shows that transport of expanded MSCs can decrease cell viability to levels

392 that would be unacceptable for clinical use. The aim of this study was to determine influence of

393 different transport factors on MSC's viability and ability to differentiate into different cell

394 lineages. We were unable to identify significant differences between conditions tested, possibly

395 due to the small sample number $(n=6)$ for each evaluated condition combined with the large

396 number of comparisons between conditions that were performed in this study. Nevertheless,

397 there are several aspects worth discussing.

398 An effect of transport media on cell survival within the positive temperature range has been 399 reported before (Garvican et al., 2014). In this previous report equine MSC viability declined 400 most rapidly in all allogenic biological fluids compared to culture medium and saline (Garvican 401 et al., 2014). This is an interesting finding, because even though we did not reach significant 402 results in our study, we observed contrary results: viability was better preserved with autologous

403 BMS or plasma vs. PBS or HyoThermosol. A potential explanation might be complement system

404 activation in allogenic but not autologous combinations resulting in increased MSC lysis. If 405 autologous products are not available, thermal treatment $\left(56^{\circ} \mathrm{C}, 30 \mathrm{~min}\right)$ of allogenic $\mathrm{BMS}$ or 
406 blood plasma may resolve this problem. Interestingly, Garvican et al. (2014), who used allogenic

407 products in the above mentioned study stated in their discussion, that pilot studies suggested

408 "that heat treatment of allogeneic plasma, bone marrow aspirate and platelet-rich plasma $\left(56^{\circ} \mathrm{C}\right.$

409 for 1 hour) resulted in a small, but measurable improvement in cell viability (J. Dudhia,

410 unpublished observation)". However, heat inactivation in turn adversely affects biological

411 products as well (Giard, 1987) and might therefore be controversial. No difference was found in

412 a study assessing equine MSC expansion in allogenic plasma lysate vs. FBS, i.e. a xenogenic

413 medium (Seo et al., 2013). Unfortunately no comments were made on complement inactivation

414 in either transport media. In contrast to that, no influence on equine MSC survival was found

415 when comparing ten different transport media encompassing PBS, DMEM, with or without the

416 addition of $20 \%$ or $80 \%$ equine serum (presumably allogenic), or $20 \%$ or $80 \%$ FBS (Bronzini et

417 al., 2012). Subsequently, PBS was recommended by the authors without further explanation. We

418 used culture medium (DMEM high glucose $+20 \%$ FBS) in part I of our study. The observed low

419 viability (37-44\%) as well as the inclusion of FBS prompted us to investigate alternative

420 transport media in part II. The addition of FBS to culture medium during transport of equine

421 MSCs was omitted on purpose by others to avoid introducing foreign materials (Mercati et al.,

422 2014). FBS is considered to potentially cause xenogenic immune reactions and may additionally

423 carry the risk of transmitting bovine pathogens such as viruses, bacteria, and prions (Sundin et

424 al., 2007). A lower degree of inflammation was observed after intraarticular injection of

425 autologous MSCs compared to allogenic or xenogenic MSCs, thus reinforcing the importance of

426 potential immunoreaction due to foreign proteins (Pigott et al., 2013).

427 We observed an unacceptably low viability after transporting MSCs within the negative

428 temperature range particularly using BMS $+10 \%$ DMSO or blood plasma $+10 \%$ DMSO. This is 
429 in contradiction to previous studies where superior viability was obtained by freezing MSCs in

$43090 \%$ allogenic blood serum $+10 \%$ DMSO, i.e. viabilities between $60-80 \%$ after $48-72 \mathrm{~h}$ were

431 observed (Garvican et al., 2014). Notably, after freezing equine MSCs in transport media

432 containing either autologous or allogenic serum or FBS no significant differences in viability and

433 growth characteristics were found (Mitchell et al., 2015). An overall high viability of 80-90\%

434 post thawing was observed. Differences between protocols may explain contradictory findings to 435 our study, for example the method of thawing. We submerged samples quickly in a $37^{\circ} \mathrm{C}$ warm

436 water bath, which is a realistic procedure for equine clinicians. Rapid thawing of mammalian

437 cells is recommended to prevent ice crystal formation and cell lysis, thus, $37^{\circ} \mathrm{C}$ is the

438 recommended thawing temperature (Katayama et al., 1997; Phelan, 2007). Contrary, Mitchell et

439 al. (2015) used a modified thawing method as a result of own pilot studies. Specifically, during

440 the thawing process PBS was added to the MSC suspension to prevent post-thaw osmotic shock.

441 They report viabilities less than $<60 \%$ during their pilot studies when using a standard thawing

442 protocol. Additionally, adding up to $20 \mathrm{ml}$ PBS causes a dilution of the transport medium

443 including the cytotoxic DMSO before the viability assessment was started; this is also in contrast

444 to our study. A similar thawing method was used by Garvican et al. (2014) as well and might

445 explain the superior viability following the freezing protocol. All of these invasive measures are

446 no feasible options in equine clinical settings. It is very likely, that thawing is performed in an

447 even less controlled manner using warm hands or pockets of pants.

448 In our study the choice of transport container may also have impacted viability during the

449 freezing process. In part I, the containers were evaluated at RT only and as result a glass syringe

450 with a rubber tipped plunger was used to freeze the MSC suspension. Previously published

451 cryoprotocols for equine MSCs stated the use of cryovials or cryotubes. In our study the material 
452 (glass, rubber) or the handling within the syringe may have negatively influenced cell viability

453 during the freezing or thawing process.

454 Another point to discuss is the use of DMSO as cryopreserving agent. DMSO was part of all

455 transport media within the negative temperature range in our study; however, at concentrations

456 used for cryopreservation and temperatures $>4^{\circ} \mathrm{C}$ DMSO is potentially cytotoxic. Adverse and

457 toxic reactions in recipient human patients have been reported (Thirumala, Goebel \& Woods,

458 2013). Finally, DMSO has been described as being capable of inducing differentiation of stem

459 cells into cardiac or neuronal-like cells (Woodbury et al., 2000; Young et al., 2004). Even though

460 Mitchell et al. (2015) did not identify a difference between MSCs after freezing in media

461 containing $5 \%$ or $10 \%$ DMSO, no comparison was made to native MSCs before the DMSO

462 contact.

463 Based on our data, no conclusion regarding the optimal transport media of choice for shipping

464 frozen equine MSCs can be made due to the overall low viability observed. The use of CryoStor

465 merits caution since to our knowledge no data are available on in vivo compatibility of this

466 product after, for example, intratendinous or intraarticular injection in horses. An alternative

467 concept practiced after transportation of human hematopoietic stem cells, is washing the MSCs

468 upon arrival, but this procedure is not feasible for most practicing veterinarians.

469 The subjectively observed declining viability of unfrozen MSCs over time ( $24 \mathrm{~h} \mathrm{vs.} 48 \mathrm{~h})$, which

470 was seen in our study in each of the compared test conditions, has been reported consistently

471 before by others (Bronzini et al., 2012; Mercati et al., 2014; Garvican et al., 2014). Interestingly,

472 Bronzini et al. (2012) assessed viability more closely during the first 24 hours, i.e. at 3, 6, 9, 12 ,

473 and $24 \mathrm{~h}$ (and further). They reported a steadily maintained viability up to $12 \mathrm{~h}$; however, a steep

474 decline in viability from $12 \mathrm{~h}$ transport time to $24 \mathrm{~h}$ was observed. It is also of no surprise that 
475 time (in our study $48 \mathrm{~h}$ vs. $72 \mathrm{~h}$ ) appeared to have far less influence on viability of MSCs in a

476 frozen state; this is in accordance with previous findings in equine MSCs (Garvican et al., 2014).

477 While there was no significant difference for temperature $\left(4^{\circ} \mathrm{C}\right.$ vs. $\left.\mathrm{RT}\right)$ in our study, an

478 advantage of lower temperatures has been previously reported (Mercati et al., 2014). However, a

479 higher rate of equine MSC survival at RT vs. $4^{\circ} \mathrm{C}$ (and $37^{\circ} \mathrm{C}$ ) was reported by one research

480 group before (Bronzini et al., 2012). There was also no influence of temperature in the negative

481 temperature range $\left(-20\right.$ vs. $\left.-80^{\circ} \mathrm{C}\right)$ in our study. Thus, during transport, it is paramount to

482 maintain temperatures at minimum below $-20^{\circ} \mathrm{C}$. Temperatures of approximately $-80^{\circ} \mathrm{C}$ are

483 preserved on dry ice but require additional effort and cost during shipment. A temperature of -

$48420^{\circ} \mathrm{C}$ may or may not be maintained with freezer packs and appropriate insulating packaging.

485 Continuous temperature measurements within the transport box might be necessary for quality

486 control as, to our knowledge, no equine studies are available concerning this practice. In clinical

487 settings, transport of suspended equine $\mathrm{MSCs}$ at $4-10^{\circ} \mathrm{C}$ was facilitated using freezer packs and

488 insulated boxes (Godwin et al., 2012).

489 There are discrepancies in MSC viability from previous publications (Mercati et al., 2014;

490 Garvican et al., 2014) compared to our findings. Interestingly, a markedly decreased viability

491 after transport of suspended MSCs to less than 50\% was observed by Bronzini et al. (2012) as

492 well. Unfortunately, based on the given description of the automated counting, it is unclear

493 whether the total cell count or just viable cells were determined. Further, differences between

494 studies might be due to the MSC source (blood, adipose tissue, BM), the quantifying technique

495 (manual vs. automated counting), individual settings within each laboratory, or other unknown

496 factors. Direct comparison of protocols is impeded by curtailed description of protocols in some

497 of the other studies (Bronzini et al., 2012). 
498 The slightly decreased viability in our control group (time 0 ) was most likely due to logistic

499 reasons: the samples for this group were handled together with the test groups, meaning that in

500 part II, 29 samples were assessed at the same time. The resulting prolonged processing time may

501 have influenced viability. This may partially account for the poor survival after freezing MSCs in

502 part II of our study too, because one condition (CryoStor, $-20^{\circ} \mathrm{C}, 72 \mathrm{~h}$ ), resulted in part II in

$50335.5 \%$ viability and in part III (where fewer samples were evaluated) in $61.8 \%$ viability. Because

504 all samples within each part of the study were handled equally, comparison between individual

505 settings in each part of the study are still valid in our opinion. This may indicate that, in the

506 clinical setting, cells should be used as soon as possible after they have been thawed.

507 Comparison with previous studies is not always possible, because control viability before

508 starting the simulated transport was not specifically evaluated (Bronzini et al., 2012; Mitchell et

509 al., 2015).

510 Also, considerable decrease of the total number of viable cells was observed in all test conditions

511 in our study. It is important to distinguish between the influence of manipulation (placement into

512 the syringe, subsequent withdrawal, cell counting procedure) alone and the actual loss in the

513 transport container during transport. The control group of part III shows that just the

514 manipulation accounts for a deficit of $28-43 \%$; higher concentrated cell suspensions appeared

515 to have less cell loss. We believe that the highest loss occurs during the cell counting procedure

516 and therefore any conclusion regarding the cell numbers a patient receives directly from a

517 transport container is not possible. A comparison to previous equine studies is not possible

518 because similar data have not been published before.

519 The undisturbed adipogenic and osteogenic differentiation throughout the study is in accordance

520 with previous findings (Mercati et al., 2014). We found that the chondrogenic differentiation 
521 appeared to be affected, though not significantly. Decreased chondrogenic differentiation may be

522 of concern because MSCs are intraarticularly applied in horses for the treatment of osteoarthritis

523 (Ferris et al., 2014) and further investigation into this possible effect is warranted.

524 Only negligible differences in recovered cell suspension volume were found when the five

525 transport containers were compared. It has to be taken into account, that in part I the containers

526 were tested at RT only; the outcome of the investigation might have been different at other

527 temperatures, e.g. below freezing. The lack in differences between the containers was

528 unexpected, because the material of our chosen transport containers varied considerably.

529 Counting the recovered cells after the simulated transport would have probably yielded further

530 useful information. Cell count was determined in some (Bronzini et al., 2012; Mercati et al.,

531 2014) but not in other (Garvican et al., 2014) previous studies evaluating the effect of transport

532 on equine MSCs.

533 We noticed that the liquid content tended to foam after agitation, making aspiration in the

534 cryotube and in the CellSeal more difficult. The foam formation in the glass syringes dissolved

535 faster compared to all other containers. Agitation is necessary because cells tend to sediment

536 quickly to the bottom of the container. We also noticed that even after agitation, cell

537 accumulations sometimes remained visible in the fluid. This was irrespective of the type of

538 container. Protein aggregation and particle formation in prefilled glass syringes is a known effect

539 in the pharmaceutical industry (Jones, Kaufmann \& Middaugh, 2005; Gerhardt et al., 2014).

540 Prefilled glass syringes and some plastic syringes contain silicon oil as a lubricant to enable

541 smooth plunger movement. It has been shown that the silicon oil-water and air-water interface

542 combined with agitation are responsible for the aggregating effect (Jones, Kaufmann \&

543 Middaugh, 2005). Injecting large protein particles might be of concern in the equine patient, but 
544 has not been evaluated specifically. Also, risk of breakage of glass syringes compared to plastic

545 containers has to be considered. In general, the use of syringes as transport containers seems

546 appealing since they are ready-to-use products. However, they are not sterile on the outside and

547 special precaution is required when using the syringes for sterile application. In contrast, a sterile

548 syringe can be used to aspirate the content from cryotubes or CellSeal. We occasionally noticed

549 that aspiration of small volumes from CellSeal was difficult and small pieces of plastic from the

550 seal blocked the $21 \mathrm{G}$ needle used for aspiration. A larger needle might have prevented that, but

551 may result in injection of small plastic pieces into patients' tissues. Additionally, the large port of

552 cryotubes may be a potential entry for contamination during sample aspiration.

553 We compared various cell concentrations during transport, because injecting small volumes and

554 therefore preparation of highly concentrated MSC suspensions might be of interest for the

555 treatment of small tendon defects. In our experience (unpublished observations) even $1 \mathrm{ml}$ MSC

556 suspension injected into small tendinous lesions (under sonographic guidance) leaked outside the

557 defect and into the peritendinous tissue. This was proven by labeling the MSCs with SPIO (iron

558 oxide particles) and subsequent sequential MRI evaluation. In clinical cases application of $2 \mathrm{ml}$

559 volume at a concentration of $5 \times 10^{6} \mathrm{MSC} / \mathrm{ml}$ has been reported (Godwin et al., 2012; Smith et

560 al., 2013). In previous experimental studies assessing MSC transport conditions comparatively

561 lower concentrations of $0.5 \times 10^{6} \mathrm{MSC} / \mathrm{ml}$ (Bronzini et al., 2012), $1 \times 10^{6} \mathrm{MSC} / \mathrm{ml}$ (Mercati et

562 al., 2014), $5 \times 10^{6} \mathrm{MSC} / \mathrm{ml}$ (Garvican et al., 2014), and $10 \times 10^{6} \mathrm{MSC} / \mathrm{ml}$ (Mitchell et al., 2015)

563 were evaluated. In our study, no negative impact on MSC viability, proliferation and

564 differentiation capacity was observed even in our highest concentrated solution of $20 \times 10^{6}$

$565 \mathrm{MSC} / \mathrm{ml}$. 
566 The high number of comparisons within our study necessitated the application of Bonferroni

567 correction. This fact combined with the observed high variability and low samples numbers are 568 probably the reason for the lack of statistical significance.

569

570 Conclusion

571

572 In summary, we could not statistically prove any of our three hypotheses. However, transport

573 media, transport time and the temperature during transport seem to be critical factors potentially 574 influencing MSC quality.

575

576 References

577 1. Almodóvar J, Bacon S, Gogolski J, Kisiday JD, Kipper MJ. 2010. Polysaccharide-based

578 polyelectrolyte multilayer surface coatings can enhance mesenchymal stem cell response to

579 adsorbed growth factors. Biomacromolecules 11:2629-2639. DOI 10.1021/bm1005799.

580 2. Bronzini I, Patruno M, Iacopetti I, Martinello T. 2012. Influence of temperature, time and

581 different media on mesenchymal stromal cells shipped for clinical application. Veterinary

$582 \quad$ Journal 194:121-123. DOI 10.1016/j.tvj1.2012.03.010.

583 3. Costa E, Usall J, Teixidó N, Garcia N, Viñas I. 2000. Effect of protective agents, rehydration 584 media and initial cell concentration on viability of Pantoea agglomerans strain CPA-2

585 subjected to freeze-drying. 89:793-800.

586 4. Delling U, Lindner K, Ribitsch I, Jülke H, Brehm W. 2012. Comparison of bone marrow 587 aspiration at the sternum and the tuber coxae in middle-aged horses. Canadian Journal of $588 \quad$ Veterinary Research 76:52-56. 
589 5. De Loecker W, Koptelov VA, Grischenko VI, De Loecker P. 1998. Effects of cell

590 concentration on viability and metabolic activity during cryopreservation. Cryobiology

$591 \quad 37: 103-109$.

592 6. Dlimi A. 2012. Einfluss der Konzentration unterschiedlicher Zellpopulationen auf die

593 Vitalität kryokonservierter Stammzellkonzentrate [German; Influence of concentration of

594 various cell populations of the viabilty in stem cell preparations] Dissertation Dr.med.,

595 University of Erlangen-Nürnberg, Germany.

596 7. Ferris DJ, Frisbie DD, Kisiday JD, McIlwraith CW, Hague BA, Major MD, Schneider RK,

597 Zubrod CJ, Kawcak CE, Goodrich LR. 2014. Clinical outcome after intra-articular

598 administration of bone marrow derived mesenchymal stem cells in 33 horses with stifle

599 injury. Veterinary Surgery 43:255-265. DOI 10.1111/j.1532-950X.2014.12100.x.

600 8. François M, Copland IB, Yuan S, Romieu-Mourez R, Waller EK, Galipeau J. 2012.

601 Cryopreserved mesenchymal stromal cells display impaired immunosuppressive properties as

602 a result of heat-shock response and impaired interferon- $\gamma$ licensing. Cytotherapy 14:147-152.

$603 \quad$ DOI $10.3109 / 14653249.2011 .623691$.

604 9. Garvican ER, Cree S, Bull L, Smith RKW, Dudhia J. 2014. Viability of equine mesenchymal

605 stem cells during transport and implantation. Stem Cell Research \& Therapy 5:94. DOI

$606 \quad 10.1186 /$ scrt483.

607 10. Gerhardt A, Mcgraw NR, Schwartz DK, Bee JS, Carpenter JF, Randolph TW. 2014. Protein

608 aggregation and particle formation in prefilled glass syringes. Journal of Pharmaceutical

$609 \quad$ Sciences 103:1601-1612. DOI 10.1002/jps.23973.

610 11. Giard DJ. 1987. Routine heat inactivation of serum reduces its capacity to promote cell

611 attachment. In Vitro Cellular \& Developmental Biology 23:691-697. 
612 12. Giovannini S, Brehm W, Mainil-Varlet P, Nesic D. 2008. Multilineage differentiation

613 potential of equine blood-derived fibroblast-like cells. Differentiation 76:118-129.

614 13. Godwin EE, Young NJ, Dudhia J, Beamish IC, Smith RKW. 2012. Implantation of bone

615 marrow-derived mesenchymal stem cells demonstrates improved outcome in horses with

616 overstrain injury of the superficial digital flexor tendon. Equine Veterinary Journal 44:25-32.

617 DOI 10.1111/j.2042-3306.2011.00363.x.

618 14. Grogan SP, Barbero A, Winkelmann V, Rieser F, Fitzsimons JS, O’Driscoll, Martin I,

619 Mainil-Varlet P. 2006. Visual histological grading system for the evaluation of in vitro-

620 generated neocartilage. Tissue Engineering 12:2141-2149.

621 15. Guercio A, Di Marco P, Casella S, Cannella V, Russotto L, Purpari G, Di Bella S, Piccione

622 G. 2012. Production of canine mesenchymal stem cells from adipose tissue and their

623 application in dogs with chronic osteoarthritis of the humeroradial joints. Cell Biology

624 International 36:189-194. DOI 10.1042/CBI20110304.

625 16. Jones LS, Kaufmann A, Middaugh CR. 2005. Silicone oil induced aggregation of proteins.

626 Journal of Pharmaceutical Sciences 94:918-927.

627 17. Katayama Y, Yano T, Bessho A, Deguchi S, Sunami K, Mahmut N, Shinagawa K, Omoto E,

628 Makino S, Miyamoto T, Mizuno S, Fukuda T, Eto T, Fujisaki T, Ohno Y, Inaba S, Niho Y,

629 Harada M. 1997. The effects of a simplified method for cryopreservation and thawing

630 procedures on peripheral blood stem cells. Bone Marrow Transplantation 19: 283-287.

631 18. Lioznov M, Dellbrügger C, Sputtek A, Fehse B, Kröger N, Zander AR. 2008. Transportation

632 and cryopreservation may impair haematopoietic stem cell function and engraftment of

633 allogeneic PBSCs, but not BM. Bone Marrow Transplantation 42:121-128. DOI

$634 \quad 10.1038 /$ bmt.2008.93. 
635 19. Mercati F, Pascucci L, Curina G, Scocco P, Tardella FM, Dall'Aglio C, Marini C, Ceccarelli

636 P. 2014. Evaluation of storage conditions on equine adipose tissue-derived multipotent

637 mesenchymal stromal cells. The Veterinary Journal 200:339-342. DOI

$638 \quad$ 10.1016/j.tvj1.2014.02.018.

639 20. Mitchell A, Rivas KA, Smith III, R, Watts AE. 2015. Cryopreservation of equine

640 mesenchymal stem cells in 95\% autologous serum and 5\% DMSO does not alter post-thaw

641 growth or morphology in vitro compared to fetal bovine serum or allogeneic serum at 20 or

$64295 \%$ and DMSO at 10 or 5. Stem Stell Research \& Therapy 6:231. DOI 10.1186/s13287-015-

$643 \quad 0230-y$.

644 21. Phelan MC. 2007. Basic techniques in mammalian cell tissue culture. Current Protocols in

$645 \quad$ Cell Biology. Chapter 1: Unit 1.1. DOI 10.1002/0471143030.cb0101s36.

646 22. Pigott JH, Ishihara A, Wellman ML, Russell DS, Bertone AL. 2013. Inflammatory effects of

647 autologous, genetically modified autologous, allogeneic, and xenogeneic mesenchymal stem

648 cells after intra-articular injection in horses. Veterinary and Comparative Orthopaedics and

649 Traumatoogyl 26:453-460. DOI 10.3415/VCOT-13-01-0008.

650 23. Seo JP, Tsuzuki N, Haneda S, Yamada K, Furuoka H, Tabata Y, Sasaki N. 2013.

651 Comparison of allogeneic platelet lysate and fetal bovine serum for in vitro expansion of

652 equine bone marrow-derived mesenchymal stem cells. Research in Veterinary Science

653 95:693-698. DOI 10.1016/j.rvsc.2013.04.024.

654 24. Sharma RR, Pollock K, Hubel A, McKenna D. 2014. Mesenchymal stem or stromal cells: a

655 review of clinical applications and manufacturing practices. Transfusion 54:1418-1437.

$656 \quad 10.1111 / \operatorname{trf} .12421$. 
657 25. Smith RK, Garvican ER, Fortier LA. 2014. The current 'state of play' of regenerative

658 medicine in horses: what the horse can tell the human. Regenerative Medicine 9:673-685.

659 DOI 10.2217/rme.14.42.

660 26. Smith RK, Werling NJ, Dakin SG, Alam R, Goodship AE, Dudhia J. 2013. Beneficial effects

661 of autologous bone marrow-derived mesenchymal stem cells in naturally occurring

662 tendinopathy. PLoS One 25;8: e75697. DOI 10.1371/journal.pone.0075697.

663 27. Sundin M, Ringdén O, Sundberg B, Nava S, Götherström C, Le Blanc K. 2007. No

664 alloantibodies against mesenchymal stromal cells, but presence of anti-fetal calf serum

665 antibodies, after transplantation in allogeneic hematopoietic stem cell recipients.

$666 \quad$ Haematologica 92:1208-1215.

667 28. Thirumala S, Goebel WS, Woods EJ. 2013. Manufacturing and banking of mesenchymal

668 stem cells. Expert Opinion on Biological Therapy 13:673-691. DOI

$669 \quad 10.1517 / 14712598.2013 .763925$.

670 29. Wang PY, Clements LR, Thissen H, Tsai WB, Voelcker NH. 2015. Screening rat

671 mesenchymal stem cell attachment and differentiation on surface chemistries using plasma

672 polymer gradients. Acta Biomaterialia 11:58-67. DOI 10.1016/j.actbio.2014.09.027.

673 30. Woodbury D, Schwarz EJ, Prockop DJ, Black IB. 2000. Adult rat and human bone marrow

674 stromal cells differentiate into neurons. Journal of Neuroscience Research 61:364-370.

675 31. Young DA, Gavrilov S, Pennington CJ, Nuttall RK, Edwards DR, Kitsis RN, Clark IM.

676 2004. Expression of metalloproteinases and inhibitors in the differentiation of P19CL6 cells

677 into cardiac myocytes. Biochemical and Biophysical Research Communications 322:759-

678765. 
1

Study design of the three parts of the study

part I

\begin{tabular}{|l|}
\hline container \\
cryotube \\
syringe \\
(plastic/plastic) \\
- syringe \\
(plastic/rubber) \\
syringe \\
(glass/rubber) \\
CellSeal (plastic) \\
\end{tabular} \mid$\rightarrow$

part II

\begin{tabular}{|c|c|c|c|}
\hline solution & temperature & time & concentration \\
\hline $\begin{array}{l}\text { PBS } \\
\text { autologous bone marrow } \\
\text { supernatant }\end{array}$ & $\begin{array}{l}\text { room } \\
\text { temperature }\end{array}$ & $24 \mathrm{~h}$ & \\
\hline $\begin{array}{l}\text { autologous plasma } \\
\text { HypoThermosol }\end{array}$ & $4^{\circ} \mathrm{C}$ & $48 \mathrm{~h}$ & \multirow{3}{*}{$\begin{array}{l}5 \times 10^{6} \text { cells } / \mathrm{ml} \\
10 \times 10^{6} \mathrm{cells} / \mathrm{ml} \\
20 \times 10^{6} \mathrm{cells} / \mathrm{ml}\end{array}$} \\
\hline $\begin{array}{l}\text { CryoStor (10\% DMSO) } \\
\text { autologous bone marrow } \\
\text { supernatant + 10\% DMSC }\end{array}$ & $-20^{\circ} \mathrm{C}$ & $48 \mathrm{~h}$ & \\
\hline $\begin{array}{l}\text { autologous blood plasma } \\
+10 \% \text { DMSO }\end{array}$ & $-80^{\circ} \mathrm{C}$ & $72 \mathrm{~h}$ & \\
\hline
\end{tabular}


2

All parts of the study: representative histological images of the scoring system to assess adipogenic, early and late osteogenic (scale bar $100 \mu \mathrm{m}$ ), and chondrogenic differentiation (scale bar $200 \mu \mathrm{m}$ )

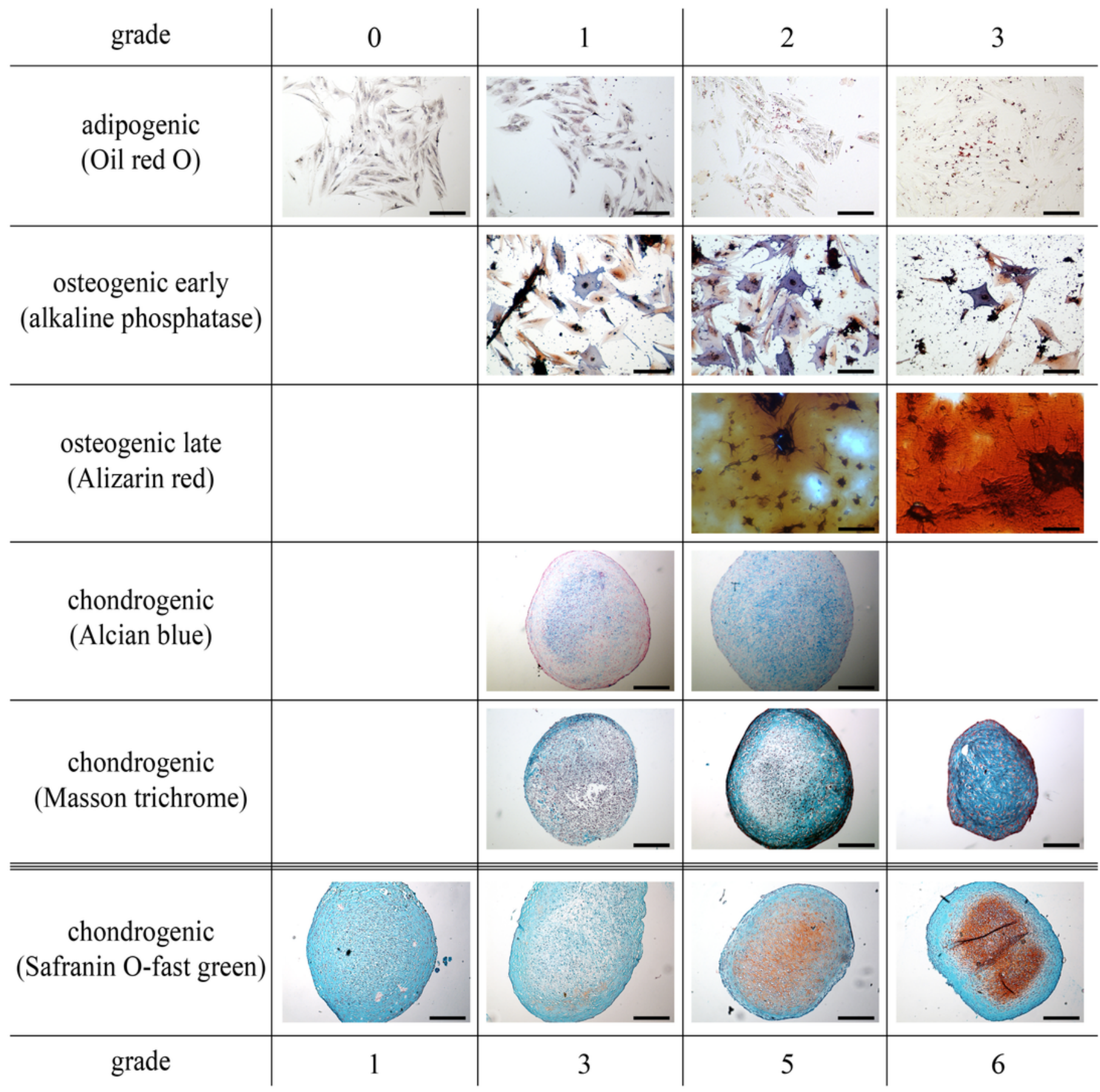


3

Part I: transport containers: 1) cryotube, 2) plastic syringe/plastic tipped plunger, 3) plastic syringe/rubber tipped plunger, 4) glass syringe/rubber tipped plunger, and 5) CellSeal
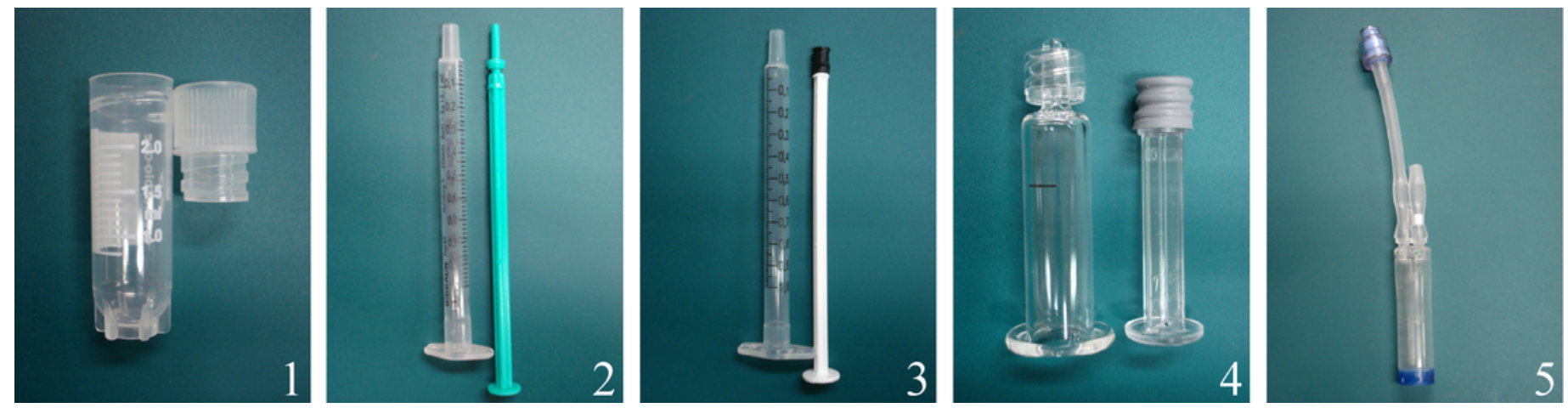
4

Part I: representative images of the five transport containers after $24 \mathrm{~h}$ "transportation" and before gentle agitation to dissolve the cell pellet formed at the bottom of the ontainer:

1) cryotube, 2) plastic syringe/plastic tipped plunger, 3) plastic syringe/rubber tipped plunger, 4) glass syringe/rubber tipped plunger, 5) CellSeal
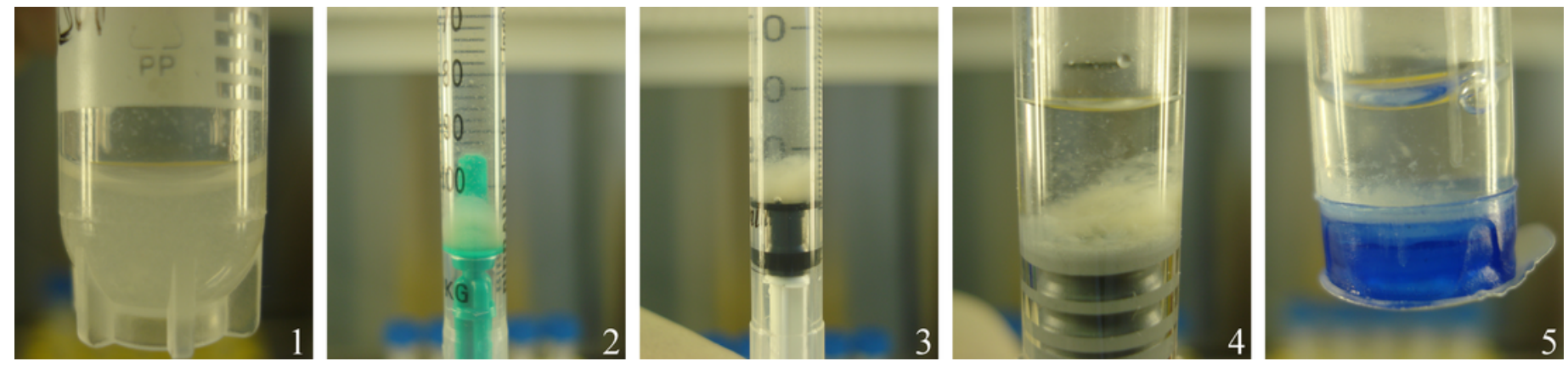
5

Part II: MSC viability

(\% Trypan Blue exclusion, median, IQR [box], range [whisker], ${ }^{\circ}$ outlier up to $1.5 \mathrm{x}$ box lengths, * extreme values, outside $3 \mathrm{x}$ box lengths) before ( $\# 0$ ) and after various "transport" conditions in a positive temperature range (\#1-16) and negative temperature range (\#1728); no significant differences $(p<0.002)$

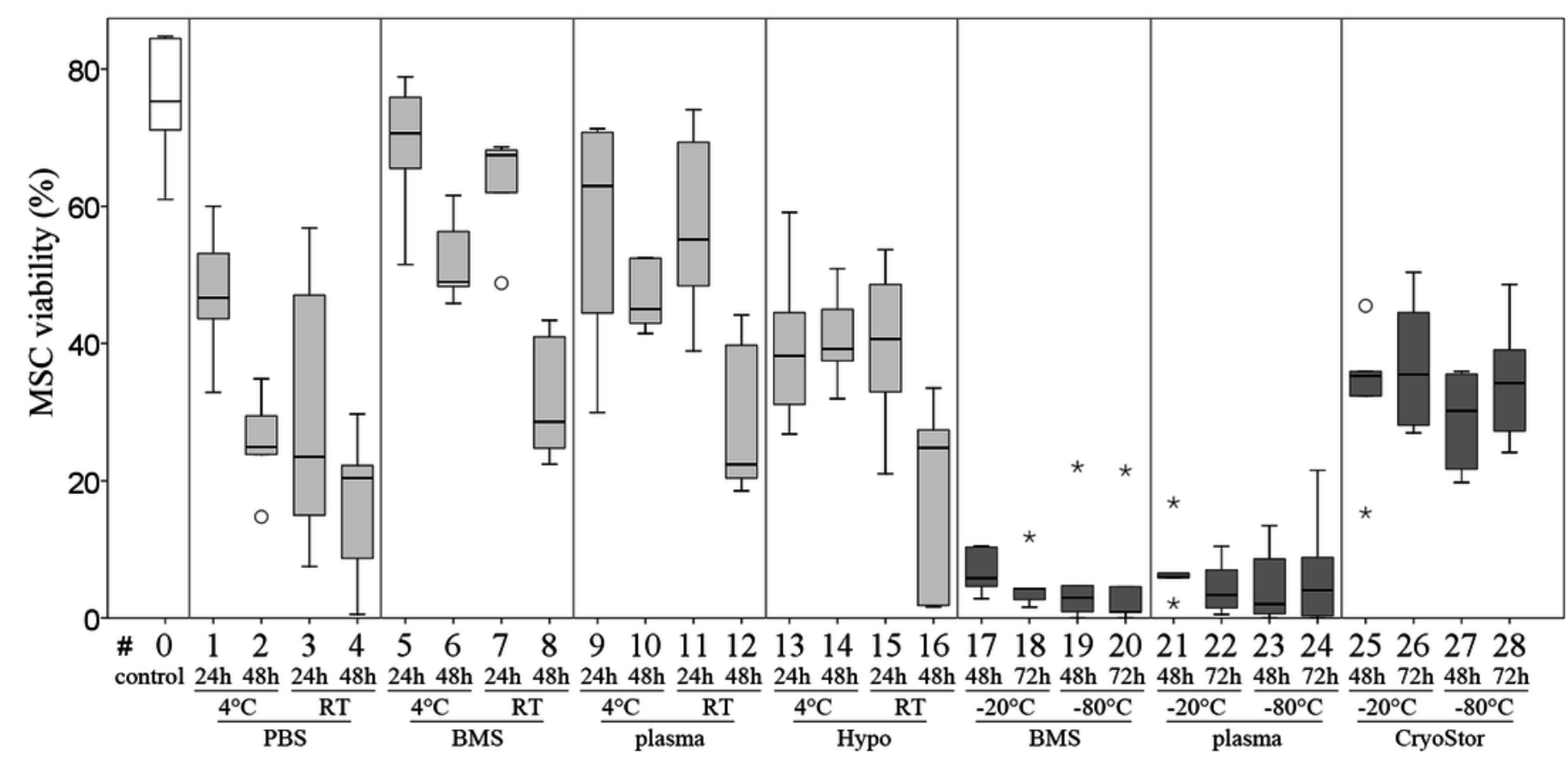


6

Part II: total numbers viable MSCs recovered

(Trypan Blue exclusion, median, IQR [box], range [whisker], ${ }^{\circ}$ outlier up to $1.5 \mathrm{x}$ box lengths, * extreme values, outside $3 \times$ box lengths) after various "transport" conditions in a positive temperature range (\#1-16) and negative temperature range (\#17-28); the dotted line at $5 \times 10^{6}$ illustrates the cell count placed into the containers at time 0

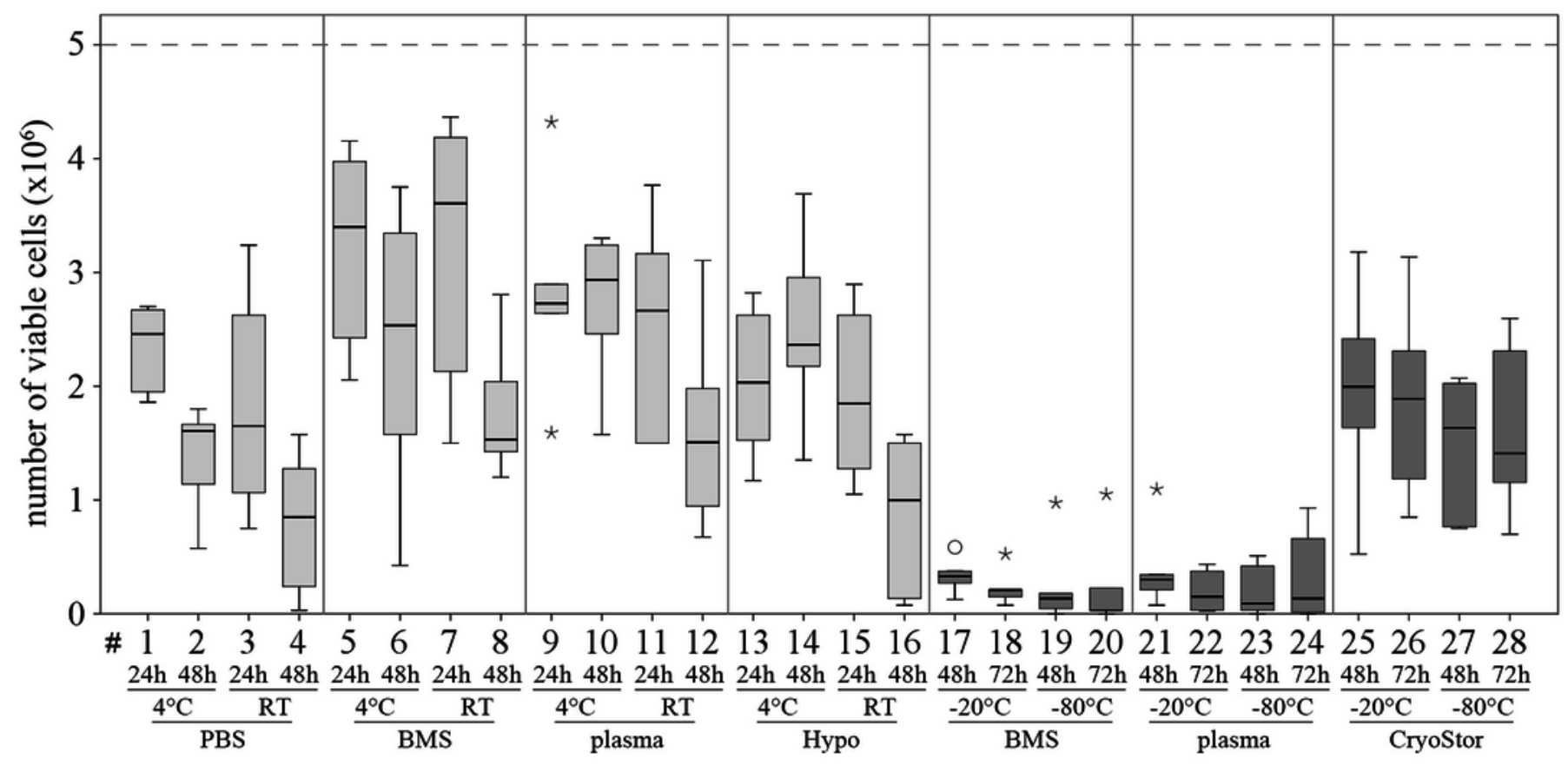




\section{7}

Part II: chondrogenic differentiation capacity:

Bern score indicating proteoglycan deposition (median, IQR [box], range [whisker]); a decrease in all test conditions compared to the control group (\#0) was noted; no significant differences $(p<0.003)$; data for \#16-24 are missing due to insufficient cell numbers after the "transport"

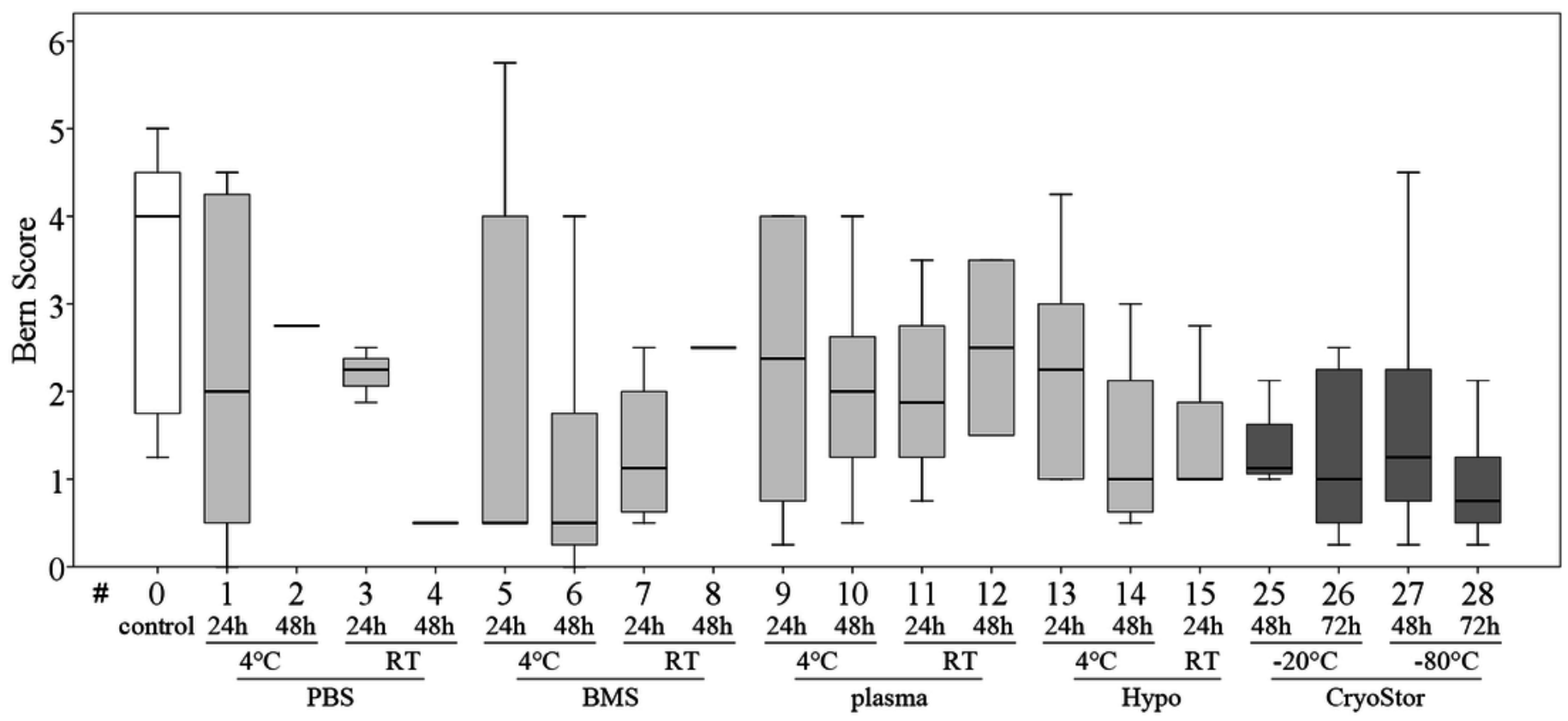


8

Part III: MSC viability

(\% Trypan Blue exclusion, median, IQR [box], range [whisker], ${ }^{\circ}$ outlier) under the influence of different cell concentrations before (control) and after "transport"

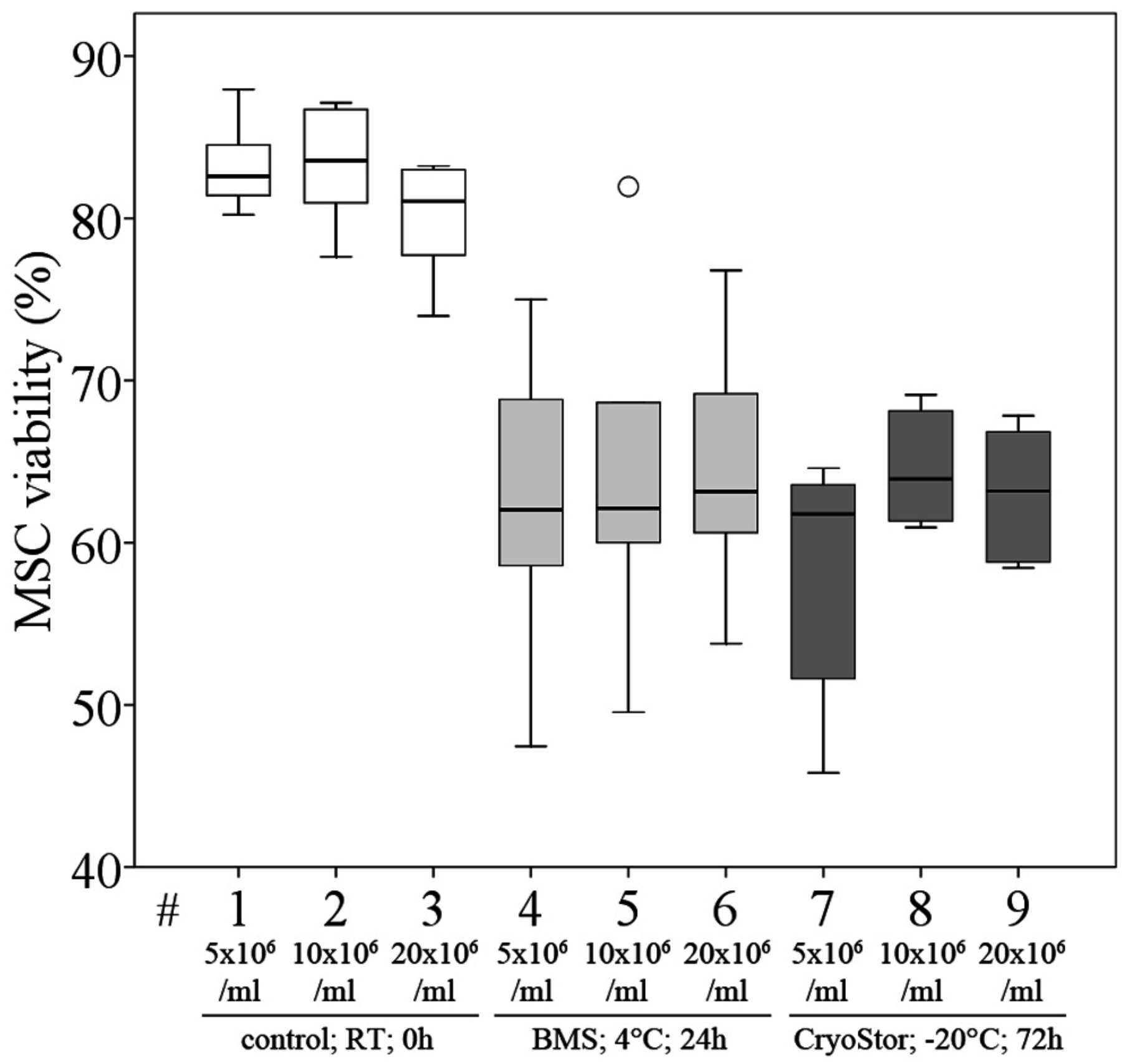




\section{Table $\mathbf{1}$ (on next page)}

Part I: MSC viability of $5 \times 10^{6} \mathrm{MSC}$ after "transport" in five different containers expressed in percent (\%) viable cells and total number viable MSCs recovered; no significant differences 
1

\begin{tabular}{lcc}
\hline & $\begin{array}{c}\text { viability in \% } \\
\text { [median (IQR)] }\end{array}$ & $\begin{array}{c}\text { total number viable MSC } \\
\text { [median (IQR)] }\end{array}$ \\
\hline control (time point 0) & $76.8(14.6)$ & not applicable \\
1- cryotube & $38.1(31.2)$ & $1.03 \times 10^{6}\left(1.77 \times 10^{6}\right)$ \\
2- plastic syringe / plastic tipped plunger & $37.4(23.9)$ & $1.85 \times 10^{6}\left(1.11 \times 10^{6}\right)$ \\
3- plastic syringe / rubber tipped plunger & $38.9(22.9)$ & $1.97 \times 10^{6}\left(1.61 \times 10^{6}\right)$ \\
4- glass syringe / rubber tipped plunger & $44.0(20.3)$ & $1.88 \times 10^{6}\left(1.13 \times 10^{6}\right)$ \\
5- CellSeal & $38.0(20.0)$ & $1.43 \times 10^{6}\left(1.20 \times 10^{6}\right)$ \\
\hline
\end{tabular}

2

3

4 


\section{Table 2 (on next page)}

Part I: chondrogenic differentiation capacity of MSCs (Bern score) after "transport" in five different transport containers,

expressed as median (IQR); container 1) cryotube, 2) plastic syringe/plastic tipped plunger, 3) plastic syringe/rubber tipped plunger, 4) glass syringe/rubber tipped plunger, and 5) CellSeal; no significant differences 


\begin{tabular}{lcccccc}
\hline & control & container & container & container & container & \multicolumn{2}{c}{ container } \\
& & 1 & 2 & 3 & 4 & 5 \\
\hline $\begin{array}{l}\text { Bern score } \\
\text { Safranin-O; }\end{array}$ & $2.3(0.9)$ & $1.3(4.1)$ & $1.0(1.1)$ & $1.5(3.1)$ & $2.3(2.5)$ & $3.0(2.8)$ \\
$0-9)$ & & & & & \\
$\begin{array}{l}\text { Alcian Blue } \\
(0-3)\end{array}$ & $1.8(0.5)$ & $1.0(0.8)$ & $1.8(0.9)$ & $2.0(0.8)$ & $1.5(0.4)$ & $1.8(0.5)$ \\
$\begin{array}{l}\text { Masson } \\
\text { Trichrome }\end{array}$ & $2.0(0)$ & $1.5(1.0)$ & $1.5(0.5)$ & $2.0(0.5)$ & $1.8(0.5)$ & $1.5(1.4)$ \\
$(0-3)$ & & & & & & \\
\hline
\end{tabular}




\section{Table 3(on next page)}

Part II: MSC viability after various "transport" conditions in a positive temperature range and negative temperature range

viability is expressed in percent (\%) viable cells and the total number viable MSCs recovered; no significant differences 


\begin{tabular}{|c|c|c|c|c|c|c|}
\hline $\begin{array}{l}\text { rank accor- } \\
\text { ding to } \% \\
\text { viability }\end{array}$ & trans & ort condition & & & $\begin{array}{l}\text { viability in } \\
\% \text { [median } \\
(\mathrm{IQR})]\end{array}$ & $\begin{array}{c}\text { total number viable } \\
\text { MSCs [median (IQR)] }\end{array}$ \\
\hline & & control & RT & 0 & $75.3(11.0)$ & not applicable \\
\hline 1 & $\# 5$ & BMS & $4^{\circ} \mathrm{C}$ & $24 \mathrm{~h}$ & $70.6(8.4)$ & $3.40 \times 10^{6}\left(1.17 \times 10^{6}\right)$ \\
\hline 2 & \#7 & BMS & $\mathrm{RT}$ & $24 \mathrm{~h}$ & $67.5(4.7)$ & $3.61 \times 10^{6}\left(1.70 \times 10^{6}\right)$ \\
\hline 3 & $\# 9$ & blood plasma & $4^{\circ} \mathrm{C}$ & $24 \mathrm{~h}$ & $63.0(23.4)$ & $2.73 \times 10^{6}\left(0.19 \times 10^{6}\right)$ \\
\hline 4 & $\# 11$ & blood plasma & $\mathrm{RT}$ & $24 \mathrm{~h}$ & $55.2(18.7)$ & $2.66 \times 10^{6}\left(1.28 \times 10^{6}\right)$ \\
\hline 5 & $\# 6$ & $\mathrm{BMS}$ & $4^{\circ} \mathrm{C}$ & $48 \mathrm{~h}$ & $49.0(6.3)$ & $2.54 \times 10^{6}\left(1.48 \times 10^{6}\right)$ \\
\hline 6 & $\# 1$ & PBS & $4^{\circ} \mathrm{C}$ & $24 \mathrm{~h}$ & $46.7(9.5)$ & $2.46 \times 10^{6}\left(0.72 \times 10^{6}\right)$ \\
\hline 7 & $\# 10$ & blood plasma & $4^{\circ} \mathrm{C}$ & $48 \mathrm{~h}$ & $45.0(8.0)$ & $2.93 \times 10^{6}\left(0.63 \times 10^{6}\right)$ \\
\hline 8 & $\# 15$ & HypoThermosol & $\mathrm{RT}$ & $24 \mathrm{~h}$ & $40.6(14.7)$ & $1.85 \times 10^{6}\left(1.03 \times 10^{6}\right)$ \\
\hline 9 & $\# 14$ & HypoThermosol & $4^{\circ} \mathrm{C}$ & $48 \mathrm{~h}$ & $39.2(6.1)$ & $2.36 \times 10^{6}\left(0.62 \times 10^{6}\right)$ \\
\hline 10 & $\# 13$ & HypoThermosol & $4^{\circ} \mathrm{C}$ & $24 \mathrm{~h}$ & $38.2(11.1)$ & $2.03 \times 10^{6}\left(0.96 \times 10^{6}\right)$ \\
\hline 11 & $\# 26$ & CryoStor & $-20^{\circ} \mathrm{C}$ & $72 \mathrm{~h}$ & $35.5(16.4)$ & $1.89 \times 10^{6}\left(1.13 \times 10^{6}\right)$ \\
\hline 12 & $\# 25$ & CryoStor & $-20^{\circ} \mathrm{C}$ & $48 \mathrm{~h}$ & $35.3(3.6)$ & $2.00 \times 10^{6}\left(0.78 \times 10^{6}\right)$ \\
\hline 13 & \#28 & CryoStor & $-80^{\circ} \mathrm{C}$ & $72 \mathrm{~h}$ & $34.2(11.8)$ & $1.41 \times 10^{6}\left(1.16 \times 10^{6}\right)$ \\
\hline 14 & $\# 27$ & CryoStor & $-80^{\circ} \mathrm{C}$ & $48 \mathrm{~h}$ & $30.2(13.8)$ & $1.64 \times 10^{6}\left(1.26 \times 10^{6}\right)$ \\
\hline 15 & $\# 8$ & BMS & RT & $48 \mathrm{~h}$ & $28.6(13.2)$ & $1.53 \times 10^{6}\left(0.48 \times 10^{6}\right)$ \\
\hline 16 & $\# 2$ & PBS & $4^{\circ} \mathrm{C}$ & $48 \mathrm{~h}$ & $24.9(5.6)$ & $1.61 \times 10^{6}\left(0.53 \times 10^{6}\right)$ \\
\hline 17 & $\# 16$ & HypoThermosol & RT & $48 \mathrm{~h}$ & $24.8(19.9)$ & $1.00 \times 10^{6}\left(1.03 \times 10^{6}\right)$ \\
\hline 18 & $\# 3$ & PBS & RT & $24 \mathrm{~h}$ & $23.5(32.1)$ & $1.65 \times 10^{6}\left(1.56 \times 10^{6}\right)$ \\
\hline 19 & $\# 12$ & blood plasma & RT & $48 \mathrm{~h}$ & $22.4(15.4)$ & $1.51 \times 10^{6}\left(0.81 \times 10^{6}\right)$ \\
\hline 20 & $\# 4$ & PBS & RT & $48 \mathrm{~h}$ & $20.4(13.5)$ & $0.85 \times 10^{6}\left(1.04 \times 10^{6}\right)$ \\
\hline 21 & \#21 & blood plasma & $-20^{\circ} \mathrm{C}$ & $48 \mathrm{~h}$ & $6.0(0.7)$ & $0.30 \times 10^{6}\left(0.14 \times 10^{6}\right)$ \\
\hline 22 & $\# 17$ & BMS & $-20^{\circ} \mathrm{C}$ & $48 \mathrm{~h}$ & $5.8(5.7)$ & $0.33 \times 10^{6}\left(0.11 \times 10^{6}\right)$ \\
\hline 23 & \#18 & BMS & $-20^{\circ} \mathrm{C}$ & $72 \mathrm{~h}$ & $4.3(1.7)$ & $0.21 \times 10^{6}\left(0.06 \times 10^{6}\right)$ \\
\hline 24 & $\# 24$ & blood plasma & $-80^{\circ} \mathrm{C}$ & $72 \mathrm{~h}$ & $4.1(8.5)$ & $0.14 \times 10^{6}\left(0.65 \times 10^{6}\right)$ \\
\hline 25 & $\# 22$ & blood plasma & $-20^{\circ} \mathrm{C}$ & $72 \mathrm{~h}$ & $3.3(5.5)$ & $0.15 \times 10^{6}\left(0.35 \times 10^{6}\right)$ \\
\hline 26 & \#19 & BMS & $-80^{\circ} \mathrm{C}$ & $48 \mathrm{~h}$ & $2.9(3.8)$ & $0.14 \times 10^{6}\left(0.14 \times 10^{6}\right)$ \\
\hline 27 & $\# 23$ & blood plasma & $-80^{\circ} \mathrm{C}$ & $48 \mathrm{~h}$ & $2.0(8.0)$ & $0.09 \times 10^{6}\left(0.39 \times 10^{6}\right)$ \\
\hline
\end{tabular}




\section{Table 4 (on next page)}

Part III: MSC viability after simulated transport using three different cell concentrations viability is expressed in percent (\%) viable cells and the total number viable MSCs recovered; in each condition $1 \mathrm{ml}$ were used; no significant differences 


\begin{tabular}{lcc}
\hline & $\begin{array}{c}\text { viability in } \\
\% \text { [median } \\
\text { (IQR)] }\end{array}$ & $\begin{array}{c}\text { total number viable } \\
\text { MSCs [median (IQR)] }\end{array}$ \\
\hline control; RT; 0h; $5 \times 10^{6} \mathrm{MSC} / \mathrm{ml}$ & $82.6(2.9)$ & $2.84 \times 10^{6}\left(1.28 \times 10^{6}\right)$ \\
control; RT; 0h; $10 \times 10^{6} \mathrm{MSC} / \mathrm{ml}$ & $83.6(4.4)$ & $6.98 \times 10^{6}\left(0.78 \times 10^{6}\right)$ \\
control; RT; 0h; $20 \times 10^{6} \mathrm{MSC} / \mathrm{ml}$ & $81.0(4.8)$ & $14.45 \times 10^{6}\left(1.46 \times 10^{6}\right)$ \\
bone marrow supernatant; $4^{\circ} \mathrm{C} ; 24 \mathrm{~h} ; 5 \times 10^{6} \mathrm{MSC} / \mathrm{ml}$ & $62.0(8.8)$ & $2.43 \times 10^{6}\left(0.25 \times 10^{6}\right)$ \\
bone marrow supernatant, $4^{\circ} \mathrm{C}, 24 \mathrm{~h} ; 10 \times 10^{6} \mathrm{MSC} / \mathrm{ml}$ & $62.1(7.2)$ & $5.38 \times 10^{6}\left(0.10 \times 10^{6}\right)$ \\
bone marrow supernatant; $4^{\circ} \mathrm{C} ; 24 \mathrm{~h} ; 20 \times 10^{6} \mathrm{MSC} / \mathrm{ml}$ & $63.2(7.3)$ & $11.33 \times 10^{6}\left(1.11 \times 10^{6}\right)$ \\
CryoStor; -20 $0^{\circ} \mathrm{C} ; 2 \mathrm{~h} ; 5 \times 10^{6} \mathrm{MSC} / \mathrm{ml}$ & $61.8(9.7)$ & $1.69 \times 10^{6}\left(0.23 \times 10^{6}\right)$ \\
CryoStor; -20 $20^{\circ} \mathrm{C} 72 \mathrm{~h} ; 10 \times 10^{6} \mathrm{MSC} / \mathrm{ml}$ & $63.9(6.2)$ & $4.28 \times 10^{6}\left(0.49 \times 10^{6}\right)$ \\
CryoStor; -20 $0^{\circ} \mathrm{C} ; 72 \mathrm{~h} ; 20 \times 10^{6} \mathrm{MSC} / \mathrm{ml}$ & $63.2(7.0)$ & $10.01 \times 10^{6}\left(2.33 \times 10^{6}\right)$ \\
\hline
\end{tabular}

